\section{开展香料研究 发展萜类化学}

中国科学院有机化学研究所 刘銡 晉

不久以前，我們响应領导的奇召来开展香料化学 的研究。大家首先明确了香料工业在我国国民經济中 的現况和它的发展前景，肯定了这是一項有重大意义 的工作; 同时大家也相信通过这項任务的完成，必然 能够带动蔽类化学的发展，因此大家的信心很强，干 劲很足。

就我們国家来說，解放前根本談不上什么香料工 业, 更說不到什么香料化学研究了。近年以来, 由于 党和政府的重視，香料工业才有了飞跃的发展。目前 我国芳香油的产量已名列世界前茅，天然香料单离 体、合成香料及人造香精的生产也有了相应的发展。 但是由于国內外日盆增长的需要，查料的生产还是供 不应求。而且由于生产技术水平較为落后，原油的輸 出还远較高級产品为多。造成这种局面的原因之一， 无疑的是科学技术跟不上生产的发展。因此，摆在我 們面前的任务是相当艰巨的。一方面，我們要协同其 他有关的研究单位帮助目前已有的香料工业增产新的 高級产品; 另一方面，要研究已发現的数以百計的野 生精油的成分及其綜合利用。

由于我們过去对这方面的研究没有經驗,首先, 就 有必要取得有关单位的协助，抹虚心向別人学习。目 前,我們已和輕工业部所属的香料研究室、上海油脂化 学公司所属的几个香料厂等取得联系, 抹拟定了合作 項目。最近我們还参加了在上海召开的第二屆全国香 料会議，对全国范围的香料生产及研究情况有了更进 一步的了解，扭为今后展开更广泛的协作建 立了基 础。

現在，我們全組人员都为了接受这愐新的光荣任 务而感到欢欣鼓舞，正在积极努力进行准备工作，决 心要在1960年来个“开門紅”。我們要在第一季度之內 初步建立高温气体层析設备扭掌握这项尖端技术; 同 时还要建立一个比較完整的精細分餾实驗室。我們不 但有信心完成原訂的1960年計划，而且有可能研究更 多的野生精油品种，为酶国野生植物的开发、利用作 出更多的貢献。在这些工作当中，肯定会遇到不少的 困难，但是借靠党的領导和麦持，依靠瑟众路綫和大 协作，加上我們抱定必胜的决心，堅信我們必定能够 完成任务。
力爭今年害虫发生預測

\section{預报工作更大跃进}

\author{
中国科学院昆虫研究所 朱 弘復
}

害虫发生預測預报是一項比較年青而科学內谷很 广泛的工作，是解放后我国的新兴事业之一。由于党 和政府的重視和領导以及釷众的交持和积极加，目 前全国各地害虫預測預报站攵罗棋布，已經形成一个 稠密的情报网。

中国科学院昆虫研究所对于害虫預測預报工作一 向重視，抹且很早就开始做棉蚜和蝗虫的預測預报工 作，目前对于林木害虫、粘虫和培多种棉虫都在进行 預測研究。为了在今年实現更大的跃进，不仅預測对 象的数量要增加，而且要从短期进为长期的預測。我 們訩为下列几点是促使預測預报工作更大跃进的基 础:

1. 翠众性預报一一把狽报办法和科学知識 交 給 翠众，通过实践一定会創造出許許多多的新成績。

2. 研究工作大协作一害虫預測預报工作，內 容广泛，毫涉到䚺多門学科，必須开展协作，尤其是 資料的积累和利用，需要統盘等划，然后才能得到更 多更快更好更省的效果。

3. 加速虫情报道一一虫情資料快而多，則发出 預报更准确，应用专碼电报（郎是把各种虫情詞句編 成号碼)轹方便又省费，經若千地区試用，成效良好。

4.改进調查方法一一过去調查方法翌众反映何嫌 复杂费时，今后应硋以作物为单位，把几种相近的害 虫統一調查，更可根据害虫的生物学特性綜合調查， 例如某些害虫大多在某种作物的某一部位寄生，則集 中此一部位調查。各地区的調查記載和項目也須統一口径，将来在材料分析时就不致发生困难。

5. 抓紧越冬調查和测报一一冬季是害虫休恨期, 过去在冬季多着重整理资料，目前全国各种事业大跃 进，农林业方面冬季工作正展开，害虫的越冬状态和 数量必須調查，这与預測明年的害虫发生数量有莫大 关䒺，所以应部抓紧。

6. 检查害虫在全国各地区发生情况一一过 去 对 于害虫发生規律往往着重个別的研究，这当然是必需 的，如果再从各不同地区的各种害虫发生规律来綜合 研究，会有更全面的覌点。对于某些发生規律掌握很 少的害虫, 应从速加强研究。 